http://economix.fr

\title{
Bankruptcy and the difficulty of firing
}

Document de Travail

Nicolae Stef

\section{Working Paper}

2017-26 


\title{
Bankruptcy and the difficulty of firing
}

\author{
Nicolae Stef ${ }^{1}$
}

April 2017

\begin{abstract}
Firms may use layoffs as an ex ante mechanism to avoid filing for bankruptcy. However, the national labor law may impose some restrictions that delay or hamper the firing decision of the employer. This study proposes a different legal pathway for policymakers whose goal is to reduce the use of bankruptcy without acting on the design of the bankruptcy law. Using a sample of 33 countries from 2007 to 2015, we show that the total amount of firing restrictions leads to more bankruptcies. The employer's legal obligation to notify a third party prior the dismissal of one employee tends to increase the number of bankruptcies. It is very likely that the employer's rescue strategy endures an intense ex post monitoring of the employment contracts and/or a strong legal opposition to the layoff decision from such third party. In addition, labor codes that apply priority rules in case of reemployment can increase the use of bankruptcy.
\end{abstract}

Keywords Bankruptcy, Layoff, Labor

JEL Classification G33 G38 J63 K31

1 Post-doctoral researcher, EconomiX, University of Paris Ouest - Nanterre La Défense, France, e-mail: nicolae.stef@yahoo.fr 


\section{Introduction}

One of the most important legal provision of the new French labor law adopted on August 9 2016 is the possibility of employees' dismissal on the basis of firm's economic performance. Thus, a French company faced with a decline in sales can more easily dismiss some of its employees in order to protect its own existence. Such reform made the subject of a long debate in the French society in which numerous labor unions have tried to oppose to its adoption. The main argument of French policymakers was that the new labor reform will increase the competitiveness of French companies on the European market. Nevertheless, heavier regulations of labor markets are associated with lower labor force participation and higher level of unemployment among the young population (Botero et al., 2004). Similar negative effects of such laws was also confirmed by Djankov and Ramalho (2008). Developing countries with rigid employment laws seem to be characterized by developed grey economies and higher unemployment.

Rigid labor codes also affect the input decisions of firms. According to Lafontaine and Sivadasan (2009), labor regulations that hinder firms to adjust the labor input as a response to the fluctuations of the demand can impede the growth of firms. However, such regulations increase workers' employment tenure by protecting them against job loss when firms experience negative shocks. Not surprisingly, pro-worker governments will always encourage the adoption of amendments that strengthen the bargaining power of employees. Besley and Burgess (2004) analyzed the consequences of such pro-worker political orientation in the case of India. Their study confirms that pro-worker labor market regulations diminished the level of investment, employment and productivity of the manufacturing sector. According to Klapper et al. (2006), labor regulations that protect more the employees can impede the growth of new firms. Higher costs of compliance with labor regulations may inhibit firms' entry.

As opposed to pro-worker laws, less rigid labor regulations tend to harm less the national economy. Di Tella and MacCulloch (2005) examined the main consequences of such laws in 21 countries from 1984 to 1990. After controlling for time and country fixed effects, their study shows that a higher degree of flexibility of firms to adjust labor to economic realities significantly increases the employment rate and the labor force participation rate. Hence, a certain support in favor of less rigid labor laws seems to be justified by the labor literature. However, adopting a labor 
law that diminishes the difficulty of firing does not affect only the economic environment but also the amount of work of bankruptcy institutions.

In this paper, we want to examine another financial perspective that may shed light on the ongoing debate between rigid labor laws and flexible labor laws. Consequently, our research assesses how legal restrictions of firing and the amount of such restrictions influence the national number of bankruptcies. Rational agents should try to prevent firm's default and use different economic strategies in order to favor the firm's survival. In this context, a higher difficulty of firing should increase the pressure put on bankruptcy courts by increasing the number of bankruptcies.

In order to analyze such financial consequences of firing regulations, we constructed a sample of 33 countries from 2007 to 2015 . Moreover, this study uses 4 firing restrictions provided by the World Bank such as: (1) the employer's obligation to notify a third party, e.g. a government agency, in case of the dismissal of one redundant worker, (2) the employer's obligation to consult a third party prior a collective dismissal, (3) the approval of a third party that is required for a collective dismissal and (4) the employer's obligation to apply priority rules in case of reemployment. Our estimations confirm that the presence of restrictions (1) and (4) encourages the use of bankruptcy. Furthermore, an important amount of firing restrictions also increases the use of bankruptcy in the economy. The way the layoff process is regulated by the law seems to directly affect the number of bankruptcy procedures opened in court. The estimations confirm that rigid laws that protect employees against firing are associated with a higher bankruptcy usage in the economy.

Although some studies treated the determinants of firms' exit rate such as Flynn (1991), Doi (2000) or Disney et al. (2003), firm's bankruptcy and firm's exit do not stand on a common ground. First, the firm will not automatically exit the market when the bankruptcy petition is approved by the court. Bankruptcy procedures are lengthy. According to Blazy et al. (2013), the average duration of a voluntary liquidation procedure in England is 35 months. In Netherlands, creditors have to wait on average 2 years to fully liquidate the debtor's assets (Couwenberg and de Jong, 2008). Second, the bankrupt firm will definitively exit the market when the judge will impose its removal from the national register. The deregistration dictated by the court is equivalent to the legal exit of the firm. However, a bankruptcy procedure does not always lead to such outcome. A firm can settle the creditors' claims soon after the court approved the bankruptcy petition by partially liquidating its assets. Some national bankruptcy procedures are also designed to help the debtor 
regain her financial health such as the Chapter 11 of the U.S. bankruptcy system or the Redressement judiciaire procedure of the French bankruptcy system. Stef (2017) identified 90 countries that have such reorganization procedures that may allow the survival of the debtor under the guidance of a reorganization plan voted by claimants and approved by the court.

Our research is of primary interest for public authorities confronted with a large number of bankruptcies. One legal alternative to diminish the national use of bankruptcy was suggested by Claessens and Klapper (2005). Legal systems are able to reduce the number of bankruptcies if they have a higher judicial efficiency and grant creditors an important amount of legal rights. Such alternative would be feasible for a country with efficient institutions. However, it may be difficult for a country to raise the judicial efficiency in the short term. Some legal systems are not used to provide a higher protection to creditors such as national systems of French legal origin. This study aims to propose a different legal pathway for policymakers whose goal is to reduce the use of bankruptcy without acting on the design of the bankruptcy law. As the study shows, countries with labor codes that hamper the employer's layoff decision are more prone to have a higher number of bankruptcies. By reducing the legal restrictions that slow down the layoff process policymakers can diminish the use of bankruptcy in the economy.

The study is organized as follows. Section 2 presents the main determinants of corporate bankruptcy filing rates identified in the literature and the relationship between labor codes and insolvency risk. In section 3, we present our sample of 33 countries and describe the variables used to assess the impact of the firing regulations on the number of bankruptcies. Section 4 presents our econometric methodology and the results of our estimations. The last section concludes.

\section{What drives the use of bankruptcy?}

\subsection{Determinants of corporate bankruptcy filing rates}

The fall and the rise of corporate bankruptcy filings are subject to different legal and economic factors. Adopting a new bankruptcy reform may be intended to modernize the national bankruptcy system in order to better serve the interest of claimants and debtors. Boyes and Faith (1986) showed that the implementation of the 1978 Bankruptcy Reform Act of United States increased on average by $16.6 \%$ the number of bankruptcies per month in the first two years after the adoption of the new law. However, a bankruptcy reform does not always lead to an increase of 
bankruptcies soon after its adoption. In 1986, a new insolvency act was adopted by the United Kingdom. As argued by Liu and Wilson (2002), the new law aimed to facilitate the reorganization of distressed companies and protect creditors from different malpractice. A reduction of the number of bankruptcies was recorded in the first three years following its adoption. In that period, more than 1100 companies were on average discouraged to file for bankruptcy (Liu and Wilson, 2002). In 1997, Belgium adopted a new bankruptcy law whose main purpose was to encourage the debtor's reorganization. According to Dewaelheyns and Van Hulle (2008), the Belgium reform managed to diminish the use of bankruptcy by small companies in the manufacturing and trade industries.

The variance of bankruptcy filings is also sensitive to currency fluctuations. Jacobsen and Kloster (2005) analyzed the impact of such macroeconomic factors on the number of Norwegian bankruptcies during 1991 and 2004. Their study shows that the appreciation of the local currency and the high growth of wages lead to an increase of the number of bankruptcies in 2002 . Nevertheless, when the local currency started to depreciate and the wages to record a moderate growth in 2003, the number of bankruptcies started to decline. Another determinant of bankruptcy use is the net interest payments. Cuthbertson and Hudson (1996) showed that an increase of net interest rate had a short-run positive impact on the number of British compulsory liquidations. In the long-run, firms can adapt more easily to high interest rates allowing them to avoid bankruptcy. Fiscal policy also seems to play a role in the variance of bankruptcies. Buehler et al. (2012) examined the determinants of bankruptcies in Switzerland. Bankruptcy rates are lower in Swiss regions where corporate taxes and unemployment rates are lower and local authorities finance high public investment projects. In addition, central municipalities of agglomerations tend to be characterized by lower bankruptcy rates. Furthermore, a drop in the regional property prices can increase the regional level of forced insolvencies in New Zealand (Fabling and Grimes, 2005). Hence, a decrease of the collateral value may increase the creditors' incentives to force a debtor file for bankruptcy given that the loan repayment risk is higher.

Undoubtedly, the number of bankruptcies is directly influenced by the content of the bankruptcy law. The rights granted to claimants provide a certain degree of protection that may encourage or discourage the use of bankruptcy. Claessens and Klapper (2005) examined how creditor's legal rights and the judicial efficiency of public institutions affect the bankruptcy filings of 35 countries from 1990 to 1999. Bankruptcy systems that do not impose an automatic stay on 
debtor's assets have less bankruptcies. Moreover, bankruptcy filings increase if a judgment during a reorganization procedure is rendered in less than 90 days. A greater judicial efficiency encourages the bankruptcy use. A bankruptcy system of high judicial efficiency that provides a higher degree of protection to creditors is associated with less bankruptcies. Stef (2017) extended their research by assessing the use of the liquidation procedure (31 countries) and the use of the reorganization procedure (23 countries) from 2005 to 2012. A legal interference in terms of use exists between the two bankruptcy procedures. Such interference supposes that the approval mechanism of reorganization has an impact on the use of liquidation. National bankruptcy laws that approve more easily the debtor's reorganization favor more filings of reorganization to the detriment of the liquidation procedure. The most significant legal provision that confirms the legal interference is the cram-down right of the court, i.e. judge can overcome the creditors' rejection and impose the reorganization procedure. This legal provision decreases the use of liquidation having a positive influence on the reorganization use.

\subsection{Layoffs and bankruptcy}

Firms that want to prevent filing for bankruptcy will engage in different ex ante strategies such as finding cheaper suppliers, renegotiating credit contracts, expanding on other markets, diminishing cost production, improving labor productivity, abandon unprofitable projects etc. Layoffs are also an ex ante mechanism that can prevent bankruptcy or at least delay the bankruptcy filing. When the expected costs of defending against a worker's unlawful termination lawsuit are higher, firms tend to replace firings policy, i.e. situation where few employees are displaced, with layoff policy characterized by a large number of displacements (Oyer and Schaefer, 2000). According to Pfann (2006), a firm may have strong incentives to delay the firing decision when the firing costs are higher. Hence, the firm's insolvency risk may increase when firings are delayed. Nevertheless, employees' interest are not protected only by the law but also by the unions. The unionization process seeks to raise the wages and to protect the employment of the current employees. However, Freeman and Kleiner (1999) confirm that unions have on average a rational behavior that does not drive firms out of business. Although unions are able to increase workers' compensations and slow down the economic growth of union firms, they are fully aware of the social necessity of the firm's survival. In addition, the influence of unions on the insolvency risk 
mainly depends on the size of the unions. Large size unions favor firm's termination whereas low and medium size unions are associated with a lower likelihood of firm's insolvency (Freeman and Kleiner, 1999).

The main dilemma of the employment protection is to diminish the layoff likelihood of individuals without harming the existence of the firm (Gautié, 2004). Such goal may be achieved by adopting fiscal instruments that can empower firms to use more rationally the firing policy. Blanchard and Tirole (2003) propose the taxation of layoff and the severance pay as instruments that can reduce the social cost of firings. The use of a tax on layoff should improve the layoff decision making process of firms. As noticed by Gautié (2004), such tax may also increase the financial burden of insolvent firms that are trying to recover their financial health. Nevertheless, a layoff tax paid by bankrupt firms can hinder the settlement procedure of debt if such tax is higher than the bankruptcy costs of the legal procedure.

In addition to the protection provided by the labor code, employees also benefit from certain rights granted in case the firm files for bankruptcy. The protection granted by the bankruptcy law to employees is mainly represented by a high position in the absolute priority rule that defines the payment order of the creditors' claim. For instance, employees are paid first before the secured claimants, the state and the other unsecured creditors in France. Seror (2003) sustains that employees should be protected in such scenario for two main reasons. First, employees have only one income source that is the bankrupt debtor. Unlike the debtor's suppliers that may bear the loss of a certain unpaid claim, employees have limited diversified income sources. Second, debtor will need employees if the firm is allowed to operate as a going concern under a reorganization procedure. The fully replacement of employees during such procedure may be costly. Hence, a bankrupt debtor may have an interest to keep his employees.

In this article, we will focus on a new legal determinant of the bankruptcy use that is related to the national labor law. This legal determinant deals with the legal difficulty of firing. If the labor code imposes numerous obligations on the employer prior a layoff decision, it may be possible that his strategy of saving the firm through firings will not be so successful. Hence, countries that slow down the layoff process through the legal system should have a higher degree of bankruptcy use. Nevertheless, Claessens and Klapper (2005) also analyzed how the protection degree of employees granted by the labor law determines the bankruptcy use. National laws that provide a higher degree of job security and better conditions of employment are associated with a lower number of 
bankruptcies. Such restrictive labor laws deter the entry of new firms therefore diminishing the bankruptcy use. Compared to their study, our analysis is focused solely on the difficulty of an employer to fire his employees and not on the job security or employment conditions. From our perspective, less severe regulations applied on the layoff process can be used as an ex ante mechanism to sustain the debtor's survival on the market.

\section{Data and variables}

Our sample contains data about the use of bankruptcy in 33 countries from 2007 to 2015 . We measure the annual use of bankruptcy through the number of bankruptcy filings (Bankruptcy). The data was gathered directly from bankruptcy institutions and national institutes of statistics. Appendix B details the data sources per country. In order to assess the difficulty of firing, we use 4 legal provisions provided by the World Bank. Hence, $Q 2$ is a dummy variable equal to 1 if the employer must notify a third party such as a public institution to terminate the employment contract of one redundant worker and 0 otherwise. $Q 4$ equals 1 if the employer of the firm must notify or consult a third party prior a collective dismissal and 0 otherwise. $Q 6$ identifies countries where the employer requires the approval from a third party to initiate a collective dismissal. $Q 8$ identifies labor laws that apply priority rules in case of reemployment. Furthermore, we constructed an aggregate index that captures the amount of firing restrictions. FRI is the sum between $Q 2, Q 4, Q 6$ and $Q 8$.

We use these legal provisions for three main reasons. First, the aspects allow to measure the amount of restrictions that an employer face prior a dismissal decision. The presence of such restrictions in the national labor law delays the employer's firing strategy of saving his distressed firm. Second, the 4 variables are time-variant variables. 8 out of the 33 countries of our sample modified their legal restrictions of layoff. Compared to Claessens and Klapper (2005), this time-variance of our variables will allow to integrate fixed effects in our econometric estimations. Third, the data is driven from the Doing Business Project of the World Bank which is based on certain assumptions about the worker and the employer. Thus, the worker is assumed to be a 42-year-old nonexecutive male employee that has been working for the firm for 20 years belonging to the national majority religion and race. The employer is a limited liability domestic firm from the 
manufacturing sector. However, the four legal provisions that we use are independent of the assumptions made for the worker and employer. ${ }^{2}$

The following table presents the descriptive statistics of our variables. A higher degree of bankruptcy use is encountered mainly in France, Germany, U.K. and U.S., all having an annual average value of Bankruptcy superior to 20000 opened bankruptcy procedures. Not surprisingly, France records the highest average number of bankruptcies in our sample. 59613 bankruptcy procedures are on average opened every year in France, a country whose legal system is recognized for its debtor-friendliness orientation. Conversely, United Kingdom with its creditor-friendly bankruptcy environment has on average nearly 3 times fewer bankruptcies than France. Moreover, Eastern European countries have on average a low number of bankruptcies, e.g. Bulgaria, Estonia, Latvia, Lithuania, Slovakia or Poland. Such countries have very young bankruptcy systems compared to the Western European countries. As suggested by Blazy and Stef (2016), Eastern European bankruptcy users may have a poor knowledge about the bankruptcy procedures which may lead to fewer bankruptcies. On the same note, bankruptcy procedures are also rarely used in South America, e.g. Chile, Brazil, and in Southern Asia, e.g. Korea, Singapore.

$\{$ Table 1$\}$

Table 1 shows the average values of the firing restriction variables. In 13 countries of our sample, the employer is obliged by the law to notify a third party prior the layoff of one employee (Q2). In half of the sample, the labor law obliges the employer to consult a public institution if he intends to engage in a collective dismissal $(Q 4)$. However, the employer cannot dismiss more employees without the approval of the law in 18 countries (Q6). Priority rules in case of reemployment of former employees must be applied in about $32 \%$ of the labor laws $(Q 8)$. The most restrictive firing environments are in Finland and Portugal for which FRI is equal to 4. However, 10 countries have no legal restrictions on the layoff process, i.e. FRI equals 0 . Hence, it is much harder to layoff an individual in Portugal than in U.K. and United States (U.S.). These preliminary statistics confirm that the firing regulations are not homogenous. In the following section, we will estimate the influence of such regulations on the bankruptcy use.

\footnotetext{
${ }^{2}$ According to the answers provided by the World Bank.
} 


\section{Estimations}

We will assess the propensity to file for bankruptcy using Bankruptcy. One main econometric issue in estimating the determinants of the bankruptcy use is that the bankruptcy procedure can be the result of a converted bankruptcy procedure. For instance, failing to comply with the payment schedule of the reorganization plan can determine the judge to convert the reorganization procedure into a liquidation procedure. In certain countries as France and Belgium, the bankruptcy law allows companies that initially filed for liquidation to be rescued through a reorganization procedure if such procedure is viable from an economic point of view. In addition, a firm that filed for bankruptcy for reasons of payment default can provoke their main suppliers or partners to go bankrupt if their survival is entirely dependent on the payments made by the first firm. In the light of these arguments, we will introduce the 1-year lagged value of Bankruptcy in the following econometric model:

$$
\text { Bankruptcy }_{\mathrm{i}, \mathrm{t}}=\alpha_{\mathrm{i}}+\beta_{\mathrm{t}}+\text { Firing }_{\mathrm{i}, \mathrm{t}-1}+\text { Bankruptcy }_{\mathrm{i}, \mathrm{t}-1}+Z_{\mathrm{i}, \mathrm{t}-1}+\mu_{\mathrm{i}, \mathrm{t}}
$$

where $i$ is the index of countries ranging from 1 to 33, $t$ is the year index ranging from 2007 to $2015, \alpha_{\mathrm{i}}$ is the unobserved country effect, $\beta_{\mathrm{t}}$ is the unobserved time effect, Firing ${ }_{\mathrm{i},-1}$ is a variable lagged by one year with Firing $\in\{F R I, Q 2, Q 4, Q 6, Q 8\}, Z_{\mathrm{i}, \mathrm{t}-1}$ is a set of control variables lagged by 1 year and $\mu_{\mathrm{i}, \mathrm{t}}$ is the error term. We measure the difficulty of firing using the lagged values of the time-variant aggregate index $F R I$ and the legal aspects counted by $Q 2, Q 4, Q 6$ and $Q 8$. Such lagged values are justified by the fact that a layoff decision aimed to prevent bankruptcy filing requires a certain time period in order to produce its effects. If the layoff is used as an ex ante mechanism of bankruptcy prevention, the firing decision will not be generally taken one day before submitting a bankruptcy petition.

In addition, we use a similar set of control variables as Claessens and Klapper (2005). Our estimations control for the judicial efficiency of public institutions (Rule of Law), for the amount of rights granted to claimants by the collateral and bankruptcy laws $(L R I)$, for the economic development of the country (Logarithm of the gross domestic product per capita (GDP per capita)), for the national economy's recession (Growth Rate of the national GDP) and the financial cost of debt (long term interest rate measured as a 10-year benchmark government bond yields 
$(L T I R))$. We use GDP per capita as a control variable given that large national economies should be associated with more bankruptcies compared to middle and low-income countries. Moreover, we expect that high cost of debt financing $(L T I R)$ encourages firms to open a bankruptcy procedure whereas countries with growing economies (Growth Rate) should have less bankruptcies. Claessens and Klapper (2005) argued that bankruptcy systems with high judicial efficiency that grant more rights to creditors are associated with less use of bankruptcy. Hence, we include the interaction term between Rule of Law and LRI (Rule of Law t $-1^{*} L R I_{t-1}$ ). Appendix A provides a detailed description of our variables.

$\{$ Table 2$\}$

Table 2 presents the results of our estimations. In the first column, the 1-year lagged variable FRI has no significant impact on Bankruptcy. In the second column of table 2, we introduced all the firing restrictions but none of them has a significant coefficient with the exception of $Q 2$. In addition, lagged $Q 2$ has also a positive and significant coefficient in the third column of table 2 . If the employer has to notify a third party to terminate the employment contract of one employee, such third party can delay the layoff decision by requesting additional documents that should prove that the layoff background complies with all the national labor law regulations. Moreover, the notification can be followed by a monitoring activity from regional or national department of labor rights that can be entitled by the law to check all the current employment contracts. According to Hogan (2001), labor unions monitor how the contract clauses are respected by the employer and they provide valuable information to the workers about their legal rights settled by the contract. Such ex post pressure on the employer's activity may affect his financial strategy of saving the firm.

The signs of the estimated coefficients of our control variables follow a logic path although some of them are not statistically significant such as the coefficients of GDP per capita and LTIR. Contrary to the study of Claessens and Klapper (2005), national systems with efficient public institutions that grant creditors an important amount of legal rights have no significant influence on the use of bankruptcy. In the table 2, the interaction term between Rule of Law and LRI has a non significant coefficient. One possible explanation for this result is the use of country fixed-effects that were not employed by Claessens and Klapper (2005) due to the fact that their legal variables 
were time-invariant variables. Furthermore, the bankruptcy use increases in countries that underwent an increase of the number of bankruptcies in the previous year Bankruptcy $\left._{\mathrm{t}-1}\right)$. Nevertheless, economy's growth helps companies survive longer (Growth Rate $\mathrm{t}_{\mathrm{t}-1}$ ).

We test the robustness of our results using the 2-years lagged values of our firing restriction variables on the amount of bankruptcies. We apply the same econometric approach and we use the same control variables. Table 3 presents the results of our estimations. We can notice that the layoff restrictions have a stronger explanation power when they are lagged by 2-years. In column (1), the amount of firing regulations existing in the labor law 2 years prior the bankruptcy filing $\left(F R I_{\mathrm{t}-2}\right)$ has a positive and significant impact on Bankruptcy. The total amount of firing restrictions 2-years prior the bankruptcy filing process seems to favor more bankruptcies. If such process is subject to multiple legal provisions, the employer's strategy of saving the firm through layoff may not be so successful. Hence, firm's bankruptcy will be a very probable outcome. In column (2), $Q 2_{\mathrm{t}-2}, Q 4_{\mathrm{t}-2}$ and $Q 8_{\mathrm{t}-2}$ have a significant influence on Bankruptcy. However, only the coefficients of $Q 2_{\mathrm{t}-2}$ and $Q 8_{\mathrm{t}-2}$ kept their significance in regressions of columns (3) and (6) where they are separately treated. The presence of a legal obligation to notify a third party in case of firing one employee $\left(Q 2_{\mathrm{t}-2}\right)$ in the previous 2 years encourages significantly the use of bankruptcy in the economy. Surprisingly, the existence of a legal provision that imposed the application of priority rules for reemployments 2 years before $\left(Q 8_{\mathrm{t}-2}\right)$ is a significant growth source of bankruptcy. The application of priority rules supposes that individuals that had worked for a given employer have a reemployment priority over the other candidates if the working position is again available. If the employer is obliged by the law to rehire an individual that was previously fired due to his low degree of efficiency and/or competence, such reemployment may lead to the employer's bankruptcy ceteris paribus. By restraining the hiring decision, the law may diminish the success likelihood of the employer's economic strategy in the long-term.

\section{\{Table 3$\}$}

Our econometric approach shows that the ex ante difficulty of firing can increase the degree of bankruptcy. However, this approach has two major caveats. First, the labor regulations that we considered are not exhaustive. Other firing restrictions are provided by the World Bank such as the approval from a third party for the layoff of one worker, the application of priority rules to 
redundancy dismissals or the obligation of retraining a worker prior his dismissal. Nevertheless, such regulations are time-invariant aspects which hamper the use of a fixed-effect regression. Second, the estimations do not control for the regional tendency of using the bankruptcy procedure. Although Bankruptcy measures the national number of bankruptcies, the distribution of bankruptcies is not homogeneous among the regions and/or counties of the country. A most suitable approach would be to identify such distribution and to integrate the regions instead of the countries in the estimations.

\section{Conclusion}

National labor law may impose some restrictions that delay or hamper the firing decision of the employer. As opposed to flexible laws, such rigid labor laws can be in contradiction to firms' objectives to use layoffs as an ex ante mechanism to avoid bankruptcy. Labor regulations that delay the layoff decision may incite owners and/or managers to find other rescue strategies. If no other solution cannot hamper the payment default of debts, firms may be forced to file for bankruptcy. After controlling for the economic and legal environment, time effects and country fixed-effects, our study shows that the amount of firing restrictions 2-years prior the bankruptcy triggering leads to more bankruptcies. Rigid laws with a slow down layoff process are associated with a high level of bankruptcy use. Although employees' interests benefit from such laws, it seems that the failure risk of firms tends to be higher when rescue layoff strategies cannot be so easily implemented by the firms.

Moreover, two firing regulations play a significant role as determinants of bankruptcy use. Firstly, the employer's legal obligation to notify a third party prior the dismissal of one employee increases the use of bankruptcy. It is very likely that a third party such as a public institution or a labor union act as a legal guardian for the dismissed employee. The employer may endure an intense ex post monitoring of the employment contracts and/or a strong legal opposition to the layoff decision from such third party. Secondly, labor codes that apply priority rules in case of reemployment can determine the firm's bankruptcy by harming ex post its financial health. It is very likely that the priority rules applied in case of reemployment of unskilled individuals can worsen the financial health of the firm which eventually can force the firm to file for bankruptcy. Hence, a legal alternative that could help diminish the growth of bankruptcies without modifying 
the content of the bankruptcy law could consist in acting on the content of the labor law. However, certain policymakers would want to protect employment at the expense of some bankruptcies in the economy. The trade-off between diminishing the bankruptcy risk and protecting the employees can be the subject of further research.

\section{Acknowledgements}

We are grateful to Anna Reva, Nadine Levratto and the World Bank for their invaluable research assistance. 
Table 1. Descriptive statistics

\begin{tabular}{|c|c|c|c|c|c|c|}
\hline Country & Bankruptcy & Q2 & $\mathbf{Q 4}$ & Q6 & Q8 & FRI \\
\hline Australia & 14235.63 & 0 & 0 & 0.63 & 0 & 0.44 \\
\hline Austria & 6098.50 & 1 & 1 & 0 & 1 & 3 \\
\hline Belgium & 9929.63 & 0 & 0 & 0 & 0 & 0 \\
\hline Brazil & 2044.50 & 0 & 0 & 0 & 0 & 0 \\
\hline Bulgaria & 552.75 & 0 & 0 & 0 & 0 & 0 \\
\hline Canada & 4391.38 & 0 & 0 & 0 & 0 & 0 \\
\hline Chile & 145.63 & 1 & 1 & 0 & 0 & 2 \\
\hline Czech Republic & 5365.00 & 0 & 0 & 0 & 0 & 0 \\
\hline Denmark & 4774.63 & 0 & 0 & 0 & 0 & 0 \\
\hline Estonia & 490.25 & 0.38 & 0.38 & 1 & 0.56 & 2.67 \\
\hline Finland & 2878.75 & 0.88 & 0.88 & 1 & 1 & 4 \\
\hline France & 59613.00 & 0 & 1 & 1 & 1 & 3 \\
\hline Germany & 28951.50 & 1 & 1 & 1 & 0 & 3 \\
\hline Hungary & 15959.88 & 0 & 0 & 0 & 0 & 0 \\
\hline Ireland & 1188.88 & 0.75 & 1 & 0 & 0 & 1.89 \\
\hline Italy & 11076.75 & 0.38 & 1 & 1 & 1 & 3.22 \\
\hline Japan & 12997.75 & 0 & 0 & 1 & 0 & 1 \\
\hline Korea & 1628.25 & 1 & 1 & 0 & 1 & 3 \\
\hline Latvia & 1346.88 & 0.63 & 0.63 & 1 & 0 & 2.56 \\
\hline Lithuania & 771.38 & 0 & 0 & 1 & 0 & 1 \\
\hline Netherlands & 7052.88 & 1 & 1 & 1 & 0 & 3 \\
\hline New Zealand & 1871.50 & 0 & 0 & 1 & 0 & 1 \\
\hline Norway & 4183.25 & 0 & 0 & 1 & 1 & 2 \\
\hline Poland & 688.75 & 0 & 0 & 0.88 & 1 & 2 \\
\hline Portugal & 6787.50 & 1 & 1 & 1 & 1 & 4 \\
\hline Singapore & 185.00 & 0 & 0 & 0 & 0 & 0 \\
\hline Slovakia & 1197.13 & 1 & 1 & 1 & 0 & 3 \\
\hline Slovenia & 766.63 & 0 & 0 & 0.88 & 0.89 & 1.89 \\
\hline South Africa & 3958.63 & 1 & 1 & 1 & 0 & 3 \\
\hline Spain & 5475.50 & 1 & 1 & 0 & 0 & 2 \\
\hline Sweden & 7035.13 & 0 & 1 & 1 & 1 & 3 \\
\hline U.K. & 20718.25 & 0 & 0 & 0 & 0 & 0 \\
\hline U.S. & 42132.88 & 0 & 0 & 0 & 0 & 0 \\
\hline Average & 9090.54 & 0.38 & 0.46 & 0.53 & 0.32 & 1.69 \\
\hline
\end{tabular}

Notes: Average values are provided for each country of the first column. A detailed description of the variables is provided by Appendix A. 
Table 2. Regressions of the number of bankruptcies and the firing regulations lagged by 1-year

\begin{tabular}{|c|c|c|c|c|c|c|}
\hline Independent Variables & (1) & (2) & (3) & (4) & (5) & (6) \\
\hline $\mathrm{FRI}_{\mathrm{t}-1}$ & $\begin{array}{c}0.034 \\
(0.137)\end{array}$ & & & & & \\
\hline Q2 ${ }_{t-1}$ & & $\begin{array}{l}0.215 * * \\
(0.013)\end{array}$ & $\begin{array}{c}0.117^{*} \\
(0.064)\end{array}$ & & & \\
\hline Q4 ${ }_{t-1}$ & & $\begin{array}{l}-0.165 \\
(0.243)\end{array}$ & & $\begin{array}{c}0.046 \\
(0.527)\end{array}$ & & \\
\hline Q6 $_{t-1}$ & & $\begin{array}{c}0.044 \\
(0.510)\end{array}$ & & & $\begin{array}{c}0.048 \\
(0.473)\end{array}$ & \\
\hline Q8 ${ }_{t-1}$ & & $\begin{array}{l}-0.009 \\
(0.952)\end{array}$ & & & & $\begin{array}{c}0.026 \\
(0.829)\end{array}$ \\
\hline Bankruptcies $_{\mathrm{t}-1}$ & $\begin{array}{l}0.664 * * * \\
(0.000)\end{array}$ & $\begin{array}{l}0.663 * * * \\
(0.000)\end{array}$ & $\begin{array}{l}0.665^{* * * *} \\
(0.000)\end{array}$ & $\begin{array}{l}0.665^{* * * *} \\
(0.000)\end{array}$ & $\begin{array}{l}0.664 * * * \\
(0.000)\end{array}$ & $\begin{array}{l}0.665 * * * \\
(0.000)\end{array}$ \\
\hline Rule of Law $t_{t-1}$ & $\begin{array}{l}0.678^{* *} \\
(0.018)\end{array}$ & $\begin{array}{l}0.705^{* *} \\
(0.034)\end{array}$ & $\begin{array}{l}0.650 * * \\
(0.025)\end{array}$ & $\begin{array}{l}0.647 * * \\
(0.024)\end{array}$ & $\begin{array}{l}0.692 * * \\
(0.030)\end{array}$ & $\begin{array}{l}0.654 * * \\
(0.022)\end{array}$ \\
\hline $\mathrm{LRI}_{\mathrm{t}-1}$ & $\begin{array}{l}0.128 * * \\
(0.032)\end{array}$ & $\begin{array}{l}0.129 * * \\
(0.046)\end{array}$ & $\begin{array}{l}0.123 * * \\
(0.041)\end{array}$ & $\begin{array}{l}0.123 * * \\
(0.037)\end{array}$ & $\begin{array}{l}0.128 * * \\
(0.041)\end{array}$ & $\begin{array}{l}0.124 * * \\
(0.033)\end{array}$ \\
\hline Rule of Law ${ }_{t-1} *$ LRI $_{t-1}$ & $\begin{array}{l}-0.067 \\
(0.108)\end{array}$ & $\begin{array}{l}-0.069 \\
(0.146)\end{array}$ & $\begin{array}{l}-0.062 \\
(0.141)\end{array}$ & $\begin{array}{l}-0.064 \\
(0.130)\end{array}$ & $\begin{array}{l}-0.070 \\
(0.128)\end{array}$ & $\begin{array}{l}-0.065 \\
(0.117)\end{array}$ \\
\hline Logarithm (GDP per capita) ${ }_{t-1}$ & $\begin{array}{l}-0.063 \\
(0.892)\end{array}$ & $\begin{array}{l}-0.071 \\
(0.881)\end{array}$ & $\begin{array}{l}-0.035 \\
(0.938)\end{array}$ & $\begin{array}{l}-0.039 \\
(0.931)\end{array}$ & $\begin{array}{l}-0.076 \\
(0.877)\end{array}$ & $\begin{array}{l}-0.044 \\
(0.924)\end{array}$ \\
\hline Growth Rate $_{\mathrm{t}-1}$ & $\begin{array}{l}-0.012 * * \\
(0.011)\end{array}$ & $\begin{array}{l}-0.013 * * * \\
(0.009)\end{array}$ & $\begin{array}{l}-0.013^{* * * *} \\
(0.008)\end{array}$ & $\begin{array}{l}-0.012 * * \\
(0.011)\end{array}$ & $\begin{array}{l}-0.012 * * * \\
(0.009)\end{array}$ & $\begin{array}{l}-0.012 * * * \\
(0.016)\end{array}$ \\
\hline LTIR $_{t-1}$ & $\begin{array}{l}-0.005 \\
(0.718)\end{array}$ & $\begin{array}{l}-0.006 \\
(0.673)\end{array}$ & $\begin{array}{l}-0.007 \\
(0.632)\end{array}$ & $\begin{array}{l}-0.004 \\
(0.776)\end{array}$ & $\begin{array}{l}-0.003 \\
(0.847)\end{array}$ & $\begin{array}{l}-0.003 \\
(0.819)\end{array}$ \\
\hline Intercept & $\begin{array}{c}1.732 \\
(0.422)\end{array}$ & $\begin{array}{c}1.795 \\
(0.407)\end{array}$ & $\begin{array}{c}1.644 \\
(0.434)\end{array}$ & $\begin{array}{c}1.693 \\
(0.430)\end{array}$ & $\begin{array}{c}1.826 \\
(0.416)\end{array}$ & $\begin{array}{r}1.718 \\
(0.428)\end{array}$ \\
\hline Observations & 297 & 297 & 297 & 297 & 297 & 297 \\
\hline Time effects & Yes & Yes & Yes & Yes & Yes & Yes \\
\hline Fixed effects & Yes & Yes & Yes & Yes & Yes & Yes \\
\hline$R^{2}$ & 0.622 & 0.625 & 0.624 & 0.621 & 0.621 & 0.621 \\
\hline
\end{tabular}

Notes: Fixed effects and time effects are included in each regression. The dependent variable is the logarithm of Bankruptcy. A detailed description of the other variables is provided in Table 1 . p-values are reported in brackets. * indicates a significant coefficient at $10 \%$. $* *$ at $5 \%$ and $* * *$ at $1 \%$. 
Table 3. Regressions of the number of bankruptcies and the firing regulations lagged by 2-years

\begin{tabular}{|c|c|c|c|c|c|c|}
\hline Independent Variables & (1) & (2) & (3) & (4) & (5) & (6) \\
\hline $\mathrm{FRI}_{\mathrm{t}-2}$ & $\begin{array}{l}0.031 * * \\
(0.014)\end{array}$ & & & & & \\
\hline $\mathrm{Q} 2_{\mathrm{t}-2}$ & & $\begin{array}{l}0.263 * * * \\
(0.000)\end{array}$ & $\begin{array}{l}0.104 * * \\
(0.016)\end{array}$ & & & \\
\hline Q4 ${ }_{t-2}$ & & $\begin{array}{l}-0.264 * * * \\
(0.004)\end{array}$ & & $\begin{array}{c}0.055 \\
(0.122)\end{array}$ & & \\
\hline Q6 ${ }_{t-2}$ & & $\begin{array}{c}0.032 \\
(0.717)\end{array}$ & & & $\begin{array}{c}0.033 \\
(0.699)\end{array}$ & \\
\hline Q8 ${ }_{t-2}$ & & $\begin{array}{c}0.071^{*} \\
(0.066)\end{array}$ & & & & $\begin{array}{l}0.075 * * \\
(0.028)\end{array}$ \\
\hline Bankruptcies ${ }_{t-1}$ & $\begin{array}{l}0.571 * * * \\
(0.000)\end{array}$ & $\begin{array}{l}0.566^{* * * *} \\
(0.000)\end{array}$ & $\begin{array}{l}0.570 * * * \\
(0.000)\end{array}$ & $\begin{array}{l}0.573 * * * \\
(0.000)\end{array}$ & $\begin{array}{l}0.572 * * * \\
(0.000)\end{array}$ & $\begin{array}{l}0.573 * * * \\
(0.000)\end{array}$ \\
\hline Rule of Law $t_{t-1}$ & $\begin{array}{c}0.466 \\
(0.162)\end{array}$ & $\begin{array}{c}0.515 \\
(0.206)\end{array}$ & $\begin{array}{c}0.441 \\
(0.183)\end{array}$ & $\begin{array}{c}0.428 \\
(0.198)\end{array}$ & $\begin{array}{c}0.465 \\
(0.239)\end{array}$ & $\begin{array}{c}0.440 \\
(0.183)\end{array}$ \\
\hline $\mathrm{LRI}_{\mathrm{t}-1}$ & $\begin{array}{c}0.098 \\
(0.150)\end{array}$ & $\begin{array}{c}0.103 \\
(0.186)\end{array}$ & $\begin{array}{c}0.094 \\
(0.170)\end{array}$ & $\begin{array}{c}0.093 \\
(0.171)\end{array}$ & $\begin{array}{c}0.098 \\
(0.196)\end{array}$ & $\begin{array}{c}0.096 \\
(0.151)\end{array}$ \\
\hline Rule of Law ${ }_{t-1} *$ LRI $_{t-1}$ & $\begin{array}{l}-0.039 \\
(0.417)\end{array}$ & $\begin{array}{c}-0.043 \\
(0.475)\end{array}$ & $\begin{array}{l}-0.034 \\
(0.481)\end{array}$ & $\begin{array}{c}-0.034 \\
(0.474)\end{array}$ & $\begin{array}{l}-0.040 \\
(0.482)\end{array}$ & $\begin{array}{c}-0.036 \\
(0.448)\end{array}$ \\
\hline Logarithm (GDP per capita) ${ }_{t-1}$ & $\begin{array}{c}0.015 \\
(0.975)\end{array}$ & $\begin{array}{l}-0.000 \\
(0.997)\end{array}$ & $\begin{array}{r}0.033 \\
(0.948)\end{array}$ & $\begin{array}{c}0.033 \\
(0.946)\end{array}$ & $\begin{array}{r}0.008 \\
(0.987)\end{array}$ & $\begin{array}{c}0.032 \\
(0.949)\end{array}$ \\
\hline Growth Rate $_{\mathrm{t}-1}$ & $\begin{array}{l}-0.015^{* * *} \\
(0.004)\end{array}$ & $\begin{array}{l}-0.015^{* * * *} \\
(0.002)\end{array}$ & $\begin{array}{l}-0.015^{* * * *} \\
(0.003)\end{array}$ & $\begin{array}{l}-0.015^{* * * *} \\
(0.004)\end{array}$ & $\begin{array}{l}-0.015^{* * *} \\
(0.004)\end{array}$ & $\begin{array}{l}-0.015^{* * *} \\
(0.004)\end{array}$ \\
\hline LTIR $_{t-1}$ & $\begin{array}{l}-0.008 \\
(0.574)\end{array}$ & $\begin{array}{l}-0.008 \\
(0.595)\end{array}$ & $\begin{array}{l}-0.009 \\
(0.548)\end{array}$ & $\begin{array}{l}-0.008 \\
(0.594)\end{array}$ & $\begin{array}{l}-0.007 \\
(0.635)\end{array}$ & $\begin{array}{l}-0.007 \\
(0.598)\end{array}$ \\
\hline Intercept & $\begin{array}{c}2.369 \\
(0.290)\end{array}$ & $\begin{array}{c}2.438 \\
(0.302)\end{array}$ & $\begin{array}{c}2.327 \\
(0.298)\end{array}$ & $\begin{array}{c}2.346 \\
(0.295)\end{array}$ & $\begin{array}{c}2.442 \\
(0.294)\end{array}$ & $\begin{array}{c}2.329 \\
(0.301)\end{array}$ \\
\hline Observations & 264 & 264 & 264 & 264 & 264 & 264 \\
\hline Time effects & Yes & Yes & Yes & Yes & Yes & Yes \\
\hline Fixed effects & Yes & Yes & Yes & Yes & Yes & Yes \\
\hline$R^{2}$ & 0.507 & 0.510 & 0.508 & 0.507 & 0.506 & 0.507 \\
\hline
\end{tabular}

Notes: Fixed effects and time effects are included in each regression. The dependent variable is the logarithm of Bankruptcy. A detailed description of the other variables is provided in Table 1 . p-values are reported in brackets. * indicates a significant coefficient at $10 \%$. $* *$ at $5 \%$ and $* * *$ at $1 \%$. 


\section{Appendix A}

Table 4. Definition of variables

\section{Variable \\ Definition}

\begin{tabular}{|c|c|}
\hline Bankruptcy & nnual number of bankruptcy procedures opened in court. \\
\hline$Q 2$ & $\begin{array}{l}\text { Dummy variable equals } 1 \text { if the employer must notify a third party to } \\
\text { terminate one redundant worker, } 0 \text { otherwise. Source: World Bank. }\end{array}$ \\
\hline$Q 4$ & $\begin{array}{l}\text { Dummy variable equals } 1 \text { if the employer must notify or consult a third } \\
\text { party prior a collective dismissal, } 0 \text { otherwise. Source: World Bank. }\end{array}$ \\
\hline Q6 & $\begin{array}{l}\text { Dummy variable equals } 1 \text { if the employer requires approval from a third } \\
\text { party to initiate a collective dismissal, } 0 \text { otherwise. Source: World Bank. }\end{array}$ \\
\hline$Q 8$ & $\begin{array}{l}\text { Dummy variable equal } 1 \text { if priority rules must be applied for } \\
\text { reemployment, } 0 \text { otherwise. Source: World Bank. }\end{array}$ \\
\hline FRI & Firing restrictions index equal to the sum between $Q 2, Q 4, Q 6$ and $Q 8$. \\
\hline Rule of Law & $\begin{array}{l}\text { An annual index that aggregates indicators that deals with the quality of } \\
\text { contract enforcement, property rights, the police and the courts and the } \\
\text { likelihood of crime and violence. The index ranges from }-2.5 \text { to } 2.5 \text {. } \\
\text { Source: World Bank. Worldwide Governance Indicators. }\end{array}$ \\
\hline$L R I$ & $\begin{array}{l}\text { Legal rights index measures the degree to which collateral and } \\
\text { bankruptcy laws protect the rights of borrowers and lenders and thus } \\
\text { facilitate lending. The index ranges from } 0 \text { to } 10 \text {. Source: World Bank. }\end{array}$ \\
\hline GDP per capita & $\begin{array}{l}\text { Gross domestic product in current U.S. dollars divided by midyear } \\
\text { population. Source: World Bank. }\end{array}$ \\
\hline Growth Rate & $\begin{array}{l}\text { Annual percentage growth rate of GDP at market prices based on } \\
\text { constant } 2010 \text { U.S. dollars. Source: World Bank. }\end{array}$ \\
\hline LTIR & 10-year benchmark government bond yields. Source: National Banks. \\
\hline
\end{tabular}




\section{Appendix B}

Table 5. Sources of bankruptcy data

\begin{tabular}{c:l}
\hline Country & \multicolumn{1}{|c}{ Data Source } \\
\hline Australia & Australian securities \& investments commission \\
Austria & Kreditschutzverband von 1870 \\
Belgium & Statistics Belgium \\
Brazil & Serasa Experian \\
Bulgaria & Coface \\
Canada & Office of the Superintendent of Bankruptcy Canada \\
Chile & Superintendencia de Insolvencia y Reemprendimiento \\
Czech Republic & Banco Central \\
Denmark & Creditreform \\
Estonia & Statistics Denmark \\
Finland & Creditreform \\
France & Statistics Finland \\
Germany & Altares \\
Hungary & Statistisches Bundesamt \\
Ireland & Creditreform \\
Italy & Insolvency Journal \\
Japan & Cerved \\
Korea & Tokio Shoko Research \\
Latvia & The Bank of Korea \\
Lithuania & Creditreform \\
Netherlands & Creditreform \\
New Zealand & Centraal bureau voor de statistiek \\
Norway & The Insolvency and Trustee Service (ITS) \\
Poland & Statistics Norway \\
Portugal & Creditreform \\
Singapore & Racius \\
Slovakia & Insolvency \& Public Trustee's Office \\
Slovenia & Creditreform \\
South Africa & Creditreform \\
Spain & Statistics South Africa \\
Sweden & Instituto Nacional de Estadistica \\
U.K. & The Swedish Agency for Growth Policy Analysis \\
U.S. & American Bankruptcy Institute \\
\hline &
\end{tabular}




\section{References}

Besley, T., \& Burgess, R. (2004). Can labor regulation hinder economic performance? Evidence from India. The Quarterly Journal of Economics, 119(1), 91-134.

Blazy, R., Chopard, B., \& Nigam, N. (2013). Building legal indexes to explain recovery rates: An analysis of the French and English bankruptcy codes, Journal of Banking \& Finance, 37(6), 1936-1959.

Blazy, R., \& Stef, N. (2016). How do bankruptcy systems perform in Eastern Europe?, Working Paper.

Blanchard, O., \& Tirole, J., (2003). Protection de l'emploi et procédures de licenciement, Rapport pour le Conseil d'analyse économique.

Botero, J. C., Djankov, S., La Porta, R., Lopez-de-Silanes, F., \& Shleifer, A. (2004). The regulation of labor. The Quarterly Journal of Economics, 119(4), 1339-1382.

Boyes, W. J., \& Faith, R. L. (1986). Some effects of the bankruptcy reform act of 1978, The Journal of Law \& Economics, 29(1), 139-149.

Buehler, S., Kaiser, C., \& Jaeger, F. (2012). The geographic determinants of bankruptcy: Evidence from Switzerland, Small Business Economics, 39(1), 231-251.

Claessens, S., \& Klapper, L. F. (2005). Bankruptcy around the world: Explanations of its relative use, American Law and Economics Review, 7(1), 253-283.

Claessens, S., Djankov, S., \& Klapper, L. (2003). Resolution of corporate distress in East Asia, Journal of Empirical Finance, 10(1), 199-216.

Couwenberg O., \& A. de Jong. (2008). Costs and recovery rates in the Dutch liquidation-based bankruptcy system, European Journal of Law and Economics, 26, 105-127.

Cuthbertson, K., \& Hudson, J. (1996). The determinants of compulsory liquidations in the UK, The Manchester School, 64(3), 298-308.

Di Tella, R., \& MacCulloch, R. (2005). The consequences of labor market flexibility: Panel evidence based on survey data. European Economic Review, 49(5), 1225-1259.

Disney, R., Haskel, J., \& Heden, Y. (2003). Entry, exit and establishment survival in UK manufacturing, Journal of Industrial Economics, 51(1), 91-112.

Dewaelheyns, N., \& Van Hulle, C. (2008). Legal reform and aggregate small and micro business bankruptcy rates: evidence from the 1997 Belgian bankruptcy code, Small Business Economics, 31(4), 409-424.

Djankov, S., \& Ramalho, R. (2009). Employment laws in developing countries. Journal of Comparative Economics, 37(1), 3-13.

Doi, N. (2000). The determinants of firm exit in Japanese manufacturing industries, Small Business Economics, 13, 331-337.

Fabling, R., \& Grimes, A. (2005). Insolvency and economic development: regional variation and adjustment, Journal of Economics and Business, 57(4), 339-359.

Freeman, R. B., \& Kleiner, M. M. (1999). Do unions make enterprises insolvent?. Industrial and Labor Relations Review, 52(4), 510-527.

Flynn, J. E. (1991). The determinants of exit in an open economy, Small Business Economics, 3, 225-232. 
Gautié, J. (2004). Faut-il taxer plutôt que réglementer les licenciements?. Connaissance de l'emploi, (5).

Hogan, C. (2001). Enforcement of implicit employment contracts through unionization, Journal of Labor Economics, 19(1), 171-195.

Liu, J., \& Wilson, N. (2002). Corporate failure rates and the impact of the 1986 insolvency act: An econometric analysis, Managerial Finance, 28(6), 61-71.

Jacobsen, D. H., \& Kloster, T. B. (2005). What influences the number of bankruptcies?, Norges Bank, Economic Bulletin, 76(4), 191.

Klapper, L., Laeven, L., \& Rajan, R. (2006). Entry regulation as a barrier to entrepreneurship, Journal of Financial Economics, 82(3), 591-629.

Lafontaine, F., \& Sivadasan, J. (2009). Do labor market rigidities have microeconomic effects? Evidence from within the firm. American Economic Journal: Applied Economics, 1(2), 88-127.

Oyer, Paul, \& Scott Schaefer. (2000). Layoffs and Litigation, RAND Journal of Economics, 31 (Summer 2000), 345-358.

Pfann, G. A. (2006). Downsizing and heterogeneous firing costs. Review of Economics and Statistics, 88(1), 158-170.

Seror, M. L. (2003). Analyzing the Inadequacies of Employee Protections in Bankruptcy Southern California Interdisciplinary Law Journal, 13, 141-166.

Stef, N. (2017). Voting rules in bankruptcy law, Review of Law \& Economics, 13(1).

Stef, N. (2017). Interference of legal procedures in bankruptcy, Working Paper. 